\title{
Desempenho comunicativo de crianças com síndrome de Down em duas situações diferentes***
}

\author{
Communicative performance of children with Down syndrome in two \\ different situations
}

\author{
Eliza Porto-Cunha* \\ Suelly Cecilia Olivan Limongi**
}

*Fonoaudióloga. Mestre em Ciências pela Faculdade de Medicina da Universidade de São Paulo (FMUSP).

Fonoaudióloga da Prefeitura Municipal de Itapevi. Endereço para correspondência: R. Cipotânea, 51 São Paulo - SP CEP 05360-160 (slimongi@usp.br).

**Fonoaudióloga. Livre-Docente. Professora Associada do Departamento de Fisioterapia, Fonoaudiologia e Terapia Ocupacional da FMUSP.

***Trabalho Realizado no Laboratório de Investigação Fonoaudiológica em Síndromes e Alterações

Sensoriomotoras da FMUSP.

Artigo Original de Pesquisa

Artigo Submetido a Avaliação por Pares

Conflito de Interesse: não

Recebido em 28.10.2009.

Revisado em 27.07.2010.

Aceito para Publicação em 17.08.2010.

\section{Abstract}

Background: analysis of the pragmatic aspects of language in children with Down syndrome. Aim: to verify the influence of environmental and contextual variables in the pragmatic aspects of language of Down syndrome (DS) children when interacting with their caregivers and therapist, and to compare their performance in both situations. Method: participants were 15 children with DS with ages ranging from 4 to 6.11 years. Data were obtained through anamnesis, the protocol of functional communicative profile, and a socioeconomic questionnaire. Data obtained from both interaction situations (with the caregiver and with the therapist) were compared, and submitted to statistical analysis. Results: Caregiver's socioeconomic and educational levels were the variables that most had an influence on the pragmatic aspects of the child in both interaction situations. Children presented proportional rates of functional communication when compared to the data obtained for their caregivers and the communicative functions more frequently used by them were recognition of others, comment and performative. Comparisons between the interaction situations indicated no statistically significant differences concerning the children's communicative performance. Conclusion: caregivers' socioeconomic and educational levels might be considered risk factors for the development of the pragmatic aspects of language in children with DS and special attention should be given to these families during the speech-language therapeutic process. Independently of the interlocutor, these children were able to initiate and maintain communication, using communicative means and functions in a similar fashion.

Key Words: Down Syndrome; Communication; Language; Child.

\section{Resumo}

Tema: análise dos aspectos pragmáticos da linguagem de crianças com síndrome de Down. Objetivo: verificar influência de variáveis ambientais e contextuais nos aspectos pragmáticos da linguagem de crianças com síndrome de Down, na interação com seu cuidador e com seu terapeuta e comparar o desempenho da criança nas duas situações. Método: participaram desse estudo 15 crianças com síndrome de Down, com idade entre 4 e 6:11 anos. Os dados foram obtidos por meio de anamnese, protocolo de avaliação pragmática da linguagem e questionário para determinar o nível econômico da família. Os dados obtidos nas duas situações foram comparados e realizou-se estudo estatístico. Resultados: o nível econômico e o grau de escolaridade do cuidador foram os fatores que mais influenciaram os aspectos pragmáticos da criança nas duas situações. As crianças usaram sua comunicação de forma funcional e equilibrada em relação ao adulto e as funções comunicativas mais utilizadas por elas foram reconhecimento do outro, comentário e performativo. Foi observado que as crianças apresentaram desempenho comunicativo semelhante nas duas situações. Conclusão: o baixo nível econômico da família e o baixo grau de escolaridade do cuidador podem ser considerados como fatores de risco para o desenvolvimento dos aspectos pragmáticos da linguagem de crianças com SD e essas famílias devem ter atenção especial do fonoaudiólogo durante o processo terapêutico. Independente do interlocutor, essas crianças foram capazes de iniciar e manter a comunicação, utilizando os modos e funções comunicativas de forma semelhante.

Palavras-Chave: Síndrome de Down; Comunicação; Linguagem; Criança. 


\section{Introduction}

Pragmatics studies the competency involved in communication interaction, independently of the communicative means used by the interlocutors1-3. The literature on language development of children with Down syndrome (DS) reports the presence of deficits in the verbal mode and speech intelligibility that are generally compensated by the use of gestures and vocalizations4-13. The verbal unintelligibility does not limit their communicative attempts and the socialinteractive language is usually a strength for children with DS14-16, since they present high rates of intentional communication with predominance of comments (C) and acknowledgments4. The opportunity of life experience is an aspect that influences the pragmatic abilities in these children17.

In the family environment, the children might be overprotected or be exposed to risk factors for their development. Under this perspective, the family economic level, parents' education and family attachments are thought to influence child development18-20. The parents and caregivers' motivation concerning the child's communication possibilities is as important as the knowledge of the family social and economic conditions21-22. The valorization and integration of parents and caregivers in the therapeutic process strength the work carried out in therapy21, providing the children with higher possibilities for their development.

The aims of this study were: to verify the influence of contextual and environmental variables on language pragmatic aspects in children with DS; and to compare the functional use of language when interacting with caregiver and with speech-language therapist.

\section{Method}

The consent form was signed by all participants' legal guardians. This research was approved by the Ethics Committee for Research Projects Analysis of the Clinical Hospital of the School of Medicine of the University of São Paulo (FMUSP), under protocol n838/05.

Fifteen children with DS participated in this research, according to the following inclusion criteria: having free trissomy of chromosome 21 diagnosis; having good health conditions; having periodic pediatric and audiological checkups; having normal results on audiological evaluation; being placed at the pre-operational period of cognitive development, according to the Genetic Epistemology theoretical model; being between 4 and 6:11 years old; attending speech-language therapy at the Speech Language Pathology
Laboratory in Syndromes and Sensorimotor Deficits (SLPL-SSD) of the Department of Physiotherapy, Communication Sciences and Occupational Therapy of the FMUSP for at least one year; and attending regular school for at least one year. The exclusion criteria involved the presence of other associated pathology; and the presence of congenital heart disease that qualifies for surgery intervention.

The data collection was carried out using a box of toys previously selected in order to assure the possibility of adult-child interaction; digital video camera and specific protocols for pragmatics analysis23.

Two interaction situations were considered: A (therapist-child) and B (caregiver-child).

We considered as caregiver, the person who accompanied the child on speech-language therapy and received all the information concerning the child's treatment and language development 24 . The caregiver should also live with the child and be responsible for his or her daily care.

The procedures involved anamnesis, patients' files review, and a questionnaire was used to determine the family socioeconomic level25. In order to establish the children's cognitivedevelopmental level, a cognitive assessment was carried out26.

The children were videotaped during a 30minutes free-play interaction with therapist and caregiver at one of the speech-language therapy rooms of the SLPL-SSD. The interval between situations A (sitA) and B (sitB) was at least one week and no more than one month, and its order was chosen aleatorily.

The communication functional profile was analyzed according to the proposal adopted for this study23, considering all communicative acts, modes and functions performed by the child and the adult, as well as the communicative space (CS) occupied by the child, and the number of communicative acts per minute (CAM). The communicative acts were classified according to the communicative mode verbal (VE), vocal (VO), gestural (G), gestural associated to verbal (VE+G), and gestural associated to vocal $(\mathrm{VO}+\mathrm{G})$; and according to the type of communicative function23,27, also considering their interpersonality (interpersonal function - IntFc, and non-interpersonal function NintFc). Despite the 20 types of communicative functions proposed23, only the most frequent functions, that is the functions produced in more than $10 \%$ of the sample were considered for analysis29. Fifteen of the 30 minutes of adult-child interaction were transcribed and analyzed. 
TABLE 1. Correlations between language pragmatic aspects and chronological age, family socioeconomic level, caregiver education and period of speechlanguage therapy attendance, in the situations $\mathrm{A}$ and $\mathrm{B}$

\begin{tabular}{|c|c|c|c|c|c|c|}
\hline $\begin{array}{c}\text { Pragmactic } \\
\text { Aspects }\end{array}$ & Situation & Sta & CA & $\begin{array}{c}\text { Economic } \\
\text { Level }\end{array}$ & $\begin{array}{l}\text { Caregiver } \\
\text { Education }\end{array}$ & $\begin{array}{c}\text { Perioc } \\
\text { of } \\
\text { therap }\end{array}$ \\
\hline \multirow{4}{*}{$\begin{array}{c}\text { Communicative } \\
\text { space }\end{array}$} & \multirow{2}{*}{ A } & CC & 0.635 & 0.5 & 0.393 & 0.639 \\
\hline & & $\mathrm{p}$ & $* 0.01$ & \#0.058 & 0.147 & $* 0.01$ \\
\hline & \multirow{2}{*}{ B } & CC & - & 0.296 & 0.244 & -0.10 \\
\hline & & $\mathrm{p}$ & 0.479 & 0.284 & 0.381 & 0.721 \\
\hline \multirow{4}{*}{$\begin{array}{l}\text { Communicative } \\
\text { acts per minute }\end{array}$} & \multirow{2}{*}{ A } & CC & 0.289 & 0.409 & 0.468 & $\overline{0.245}$ \\
\hline & & $\mathrm{p}$ & 0.297 & 0.13 & \#0.079 & 0.38 \\
\hline & \multirow{2}{*}{ B } & CC & 0.39 & 0.569 & 0.394 & $\overline{0.182}$ \\
\hline & & $\mathrm{p}$ & 0.15 & $* 0.027$ & 0.146 & 0.517 \\
\hline \multirow{4}{*}{ VE } & \multirow{2}{*}{ A } & $\mathrm{CC}$ & 0.402 & 0.621 & 0.457 & $\overline{0.081}$ \\
\hline & & $\mathrm{p}$ & 0.137 & $* 0.014$ & \#0.087 & 0.775 \\
\hline & \multirow{2}{*}{ B } & $\mathrm{CC}$ & 0.147 & 0.424 & 0.635 & 0.155 \\
\hline & & $\mathrm{p}$ & 0.602 & 0.115 & ${ }^{*} 0.011$ & 0.581 \\
\hline \multirow{4}{*}{ G } & \multirow{2}{*}{ A } & CC & - & -0.72 & -0.462 & 0.217 \\
\hline & & $\mathrm{p}$ & 0.258 & *0.002 & \#0.083 & 0.438 \\
\hline & \multirow{2}{*}{ B } & $\mathrm{CC}$ & -0.27 & -0.479 & -0.534 & -0.25 \\
\hline & & $\mathrm{p}$ & 0.33 & \#0.071 & $* 0.04$ & 0.352 \\
\hline \multirow{4}{*}{$\mathrm{VO}+\mathrm{G}$} & \multirow{2}{*}{ A } & $\mathrm{CC}$ & -0.34 & -0.269 & -0.378 & $\overline{-0.3}$ \\
\hline & & $\mathrm{p}$ & 0.215 & 0.332 & 0.165 & 0.277 \\
\hline & \multirow{2}{*}{ B } & CC & - & -0.257 & -0.547 & 0 \\
\hline & & $\mathrm{p}$ & 0,955 & 0.355 & $* 0.035$ & 1 \\
\hline \multirow{4}{*}{$\begin{array}{l}\text { Interpersonal } \\
\text { Function }\end{array}$} & \multirow{2}{*}{ A } & CC & 0.408 & 0.512 & 0.454 & $\overline{0.276}$ \\
\hline & & $\mathrm{p}$ & 0.131 & \#0.051 & \#0.089 & 0.319 \\
\hline & \multirow{2}{*}{ B } & CC & 0.591 & 0.494 & 0.181 & $\overline{0.394}$ \\
\hline & & $\mathrm{p}$ & $* 0.02$ & \#0.061 & 0.519 & 0.146 \\
\hline \multirow{4}{*}{$\begin{array}{c}\text { Non- } \\
\text { interpersonal } \\
\text { Function }\end{array}$} & \multirow{2}{*}{ A } & CC & - & -0.512 & -0.454 & $-0.27 t$ \\
\hline & & $\mathrm{p}$ & 0.131 & \#0.051 & \#0.089 & 0.319 \\
\hline & \multirow{2}{*}{ B } & $\mathrm{CC}$ & - & -0.494 & -0.181 & -0.39 \\
\hline & & $\mathrm{p}$ & *0.02 & \#0.061 & 0.519 & 0.146 \\
\hline \multirow{4}{*}{$\begin{array}{l}\text { Noticing the } \\
\text { other's presence }\end{array}$} & \multirow{2}{*}{ A } & CC & - & -0.296 & -0.462 & 0.04 \\
\hline & & $\mathrm{p}$ & 0.532 & 0.284 & \#0.083 & 0.887 \\
\hline & \multirow{2}{*}{ B } & CC & 0.132 & 0.233 & -0.155 & 0.259 \\
\hline & & $\mathrm{p}$ & 0.638 & 0.404 & 0.582 & 0.352 \\
\hline \multirow{4}{*}{ Comment } & A & CC & 0.202 & 0.704 & 0.87 & 0.132 \\
\hline & A & $\mathrm{p}$ & 0.47 & *0.003 & $*<0.001$ & 0.638 \\
\hline & & CC & 0.457 & 0.494 & 0.315 & 0.328 \\
\hline & B & $\mathrm{p}$ & \#0.08 & \#0.061 & 0.253 & 0.233 \\
\hline & $A$ & CC & - & -0.111 & 0.067 & -0.28 \\
\hline Performative & A & $\mathrm{p}$ & 0.339 & 0.693 & 0.812 & 0.303 \\
\hline Perrormatuve & $B$ & CC & - & -0.455 & -0.063 & -0.27 \\
\hline & B & $\mathrm{p}$ & $* 0.04$ & \#0.088 & 0.823 & 0.33 \\
\hline
\end{tabular}

The statistical analysis was carried out using the Wilcoxon signed-rank test and the Spearman Correlation. The significance level (p) adopted was 0.05 .

In order to assure the results reliability, $20 \%$ of the data were analyzed by two judges, speechlanguage pathologists with clinical experience in speech-language therapy for children with DS, and in using the methodology adopted in this study. The mean agreement was 93\% for the judge 1 and $94 \%$ for the judge 2 .

\section{Results}

The significant results or results with tendency towards significance concerning the correlations between variables are presented in Table 1.

The CS was positively correlated and significantly influenced by the variables chronological age $(\mathrm{p}=0.011)$ and period of therapy $(\mathrm{p}=0.01)$, in sitA. The CAM produced by the children was positively correlated and significantly influenced by the socioeconomic level $(\mathrm{p}=0.027)$, in sitB.

The communicative mode was significantly influenced by the socioeconomic level in sitA, and by the caregiver education in sitB. Those correlations were positive for VE (sitA: $p=0.014$; sitB: $p=0.011$ ), and negative for $G$ (sitA: $p=0.002$; sitB: $\mathrm{p}=0.04)$ and for $\mathrm{VO}+\mathrm{G}$ (sitB: $\mathrm{p}=0.035)$.

Concerning the interpersonality of communicative functions (IntFc and NintFc), significant correlation was observed for chronological age in $\operatorname{sit} B(p=0.02)$. As for the most used communicative functions, significant and positive correlations were found in sitA for the function $\mathrm{C}$, with the influence of the socioeconomic level $(p=0.003)$ and the caregiver education $(p=0.001)$. Concerning the sitB, significant negative correlation was found for the function PE, with the influence of child's chronological age ( $\mathrm{p}=0.048)$.

The results regarding the functional use of language by children in sitA in comparison to sitB are presented in Table 2.

In this study, the data were computed for each participant individually, allowing the verification of similarities and differences between the considered situations. Non-parametric summary measures were calculated (median and interquartile interval) and the obtained values were classified as similar (when pertaining to the interquartile interval) or different (when not pertaining to the interquartile interval), for each studied situation. 
For data analysis, we considered the number of children who performed differently in the two situations, observing those who obtained a higher score or percentile for a certain pragmatic aspect, in sitA (Dif - A) or in sitB (Dif - B).

The analysis of each children individually showed that $73.33 \%$ of the subjects occupied the $\mathrm{CS}(\mathrm{p}=0.014)$, produced number of CAM $(\mathrm{p}=0.018)$, produced communicative acts with $\operatorname{IntFc}(p=0.018)$, and used all the communicative modes in a similar and statistically significant way in the two situations.

The analysis of the types of communicative function most frequently used by the children revealed that the majority of them produced communicative acts with the following functions: noticing the other's presence (NO) (80\%), C (73.33\%) and PE (73.33\%), with similar rates in both situations. These results were statistically significant ( $\mathrm{p}=0.002, \mathrm{p}=0.018, \mathrm{p}=0.014$, respectively).

\section{Discussion}

The analysis of the influence of children's chronological age and the period of therapy attendance on the language pragmatic aspects showed that the older children presented larger occupation of the CS in sitA, whereas in sitB, the first factor influenced positively the interpersonality of the communicative act. In sitB, the older children tended to produce more acts with the function $\mathrm{C}$, and less acts with the function PE. This finding should be due to the larger experience of life in different contexts of these children4-5, 17.

The socioeconomic level and the caregiver education were the variables that most influenced the children's pragmatic aspects in both situations. The literature points out both as important factors that influence the development in its cognitive, social, emotional and language aspects18-20.

The influence of caregiver education was more frequent concerning the mode and communicative functions. The parents' low level education is considered as a risk factor for child development, as largely discussed in literature18-20, which points out the tendency of parents/caregivers of lower educational levels to present difficulties in understanding the speech-language therapy goals21-22, what might affect the child's communicative development.
TABLE 2. Comparison between situations A and B concerning the number of participants who presented similar or different performance for the language pragmatic aspects.

\begin{tabular}{|c|c|c|c|c|c|c|c|}
\hline \multirow{2}{*}{$\begin{array}{c}\text { Pragmatic } \\
\text { Aspects }\end{array}$} & \multicolumn{2}{|c|}{ Dif-A } & \multicolumn{2}{|c|}{ Dif -B } & \multicolumn{2}{|c|}{ similar } & \multirow{2}{*}{$\begin{array}{c}\text { Significance } \\
\text { (p) }\end{array}$} \\
\hline & $\mathrm{n}$ & $\%$ & $\mathrm{n}$ & $\%$ & $\mathrm{n}$ & $\%$ & \\
\hline $\begin{array}{l}\text { Communicative } \\
\text { space }\end{array}$ & 3 & 20 & 1 & 6.67 & 11 & 73.33 & $* 0.014$ \\
\hline $\begin{array}{l}\text { Communicative } \\
\text { acts per minute }\end{array}$ & 0 & 0 & 4 & 26.67 & 11 & 73.33 & $* 0.018$ \\
\hline VE & 0 & 0 & 4 & 26.67 & 11 & 73.33 & $* 0,018$ \\
\hline $\mathrm{VO}$ & 2 & 13.33 & 2 & 13.33 & 11 & 73.33 & $* 0.013$ \\
\hline G & 4 & 26.67 & 0 & 0 & 11 & 73.33 & $* 0.018$ \\
\hline $\mathrm{VE}+\mathrm{G}$ & 4 & 26.67 & 0 & 0 & 11 & 73.33 & $* 0.018$ \\
\hline $\mathrm{VO}+\mathrm{G}$ & 2 & 13.33 & 2 & 13.33 & 11 & 73.33 & *0.013 \\
\hline $\begin{array}{l}\text { Interpersonal } \\
\text { function }\end{array}$ & 0 & 0 & 4 & 26.67 & 11 & 73.33 & $* 0.018$ \\
\hline $\begin{array}{l}\text { Non- } \\
\text { interpersonal } \\
\text { function }\end{array}$ & 4 & 26.67 & 0 & 0 & 11 & 73.33 & $* 0.018$ \\
\hline $\begin{array}{l}\text { Noticing the } \\
\text { other's presence }\end{array}$ & 3 & 20 & 0 & 0 & 12 & 80 & $* 0.002$ \\
\hline Comment & 0 & 0 & 4 & 26.67 & 11 & 73.33 & $* 0.018$ \\
\hline Performative & 3 & 20 & 1 & 6.67 & 11 & 73.33 & *0.014 \\
\hline
\end{tabular}

* statistically significant results (p-value: 0,05 ); $\mathrm{VE}=$ verbal mode; $\mathrm{VO}=$ vocal mode; $\mathrm{G}=$ gestural mode; $\mathrm{VE}+\mathrm{G}=$ verbal mode associated to gestural mode; $\mathrm{VO}+\mathrm{G}=$ vocal mode associated to gestural mode; Dif-A= different with numerical or percent higher values in the SitA; Dif-B= different with numerical or percent higher values in the SitB, $\mathrm{n}=15$.

In the clinical practice, considering the great number of families of low income and low level education that seek for speech-language therapy in public services in our country, these factors do not should be taken as limiting for language development in children with DS. Nevertheless, these factors should be taken into consideration during the assessment and therapeutic intervention process of these children. Under this perspective, the speech-language pathologist plays an important role in the observation of these children's life conditions in the family nucleus and in the relation with their caregivers, aiming to inform and qualify them in the better possible way in order to nurture their children's language development18,22. 
The CS occupied by the children and the number of CAM produced by them revealed their ability of using language as an interactive tool in social contexts, involving the communicative intention, independently of the means used for communication2,5-7. The findings of this study showed that the majority of the children with DS were competent to communicate independently of the interlocutor, which corroborates the idea that social interactive language is one strength of these children's communication: they use language with communicative value, present initiative and communicative intention15,17.

All the children that participated in this study have attended speech-language therapy for at least two years, and although this was not a rigorously controlled variable, all of them were attending the same Laboratory, and following the same therapeutic model. Providing the caregivers with information concerning language development and how to deal with the difficulties in communication of their children with DS, in order to help facilitate their development, is a practice carried out in the therapy sessions. The data suggest that the effect of the instructions given to caregivers during the therapeutic process could have led to similar communicative interactions between child and caregiver, and between child and therapist18,21.

The parents/caregivers motivation concerning the child's communication possibilities is as important as the knowledge of the family social and economic conditions21-22. The valorization and integration of parents and caregivers in the therapeutic process strength the work carried out in therapy21.

The function $\mathrm{C}$ was the most frequent in both situations, confirming the findings in literature 4 . This function can serve as background for the occurrence of higher diversity of communicative functions28.
The function PE was the second most frequent in both situations and it refers to acts or emissions produced during familiar action schemes performed on objects, including sound effects and ritualized vocalizations produced simultaneously to the child's motor behavior23. Its high occurrence can be due to the context of interaction proposed in this study, i.e. free play situation, in which all children presented symbolic play.

The function NO probably also had its percentage of use influenced by the communicative context considered in this research. The interaction situation between two interlocutors in a structured context results in a more focused communication that leads the subject to notice the other's presence within the communicative context27. The fact that both situations presented the same characteristics may have contributed to the similar frequency of occurrence of this function in the situations A and B.

It is worth mentioning that during this research, large variation in the pragmatic aspects was observed in the children with DS, which reinforces the importance of the qualitative study of these aspects.

\section{Conclusion}

. the children's chronological age influenced the functional use of language differently in the interaction with therapist and in the interaction with caregiver;

. the socioeconomic level and the caregiver's education were the aspects that most influenced the language pragmatic aspects. Therefore, these aspects can be considered as risk factors for the development of the language pragmatic aspects in children with DS, and special attention from the speech-language pathologist should be given to these families during the therapeutic process; . the children with DS presented communicative competency independently of the interlocutor. 


\section{References}

1. Bates E. Language and context: the acquisition of pragmatics. York Academic Press; 1976.

2. Bara BG, Bucciarelli M, Colle L. Communicative abilities in autism: evidence for attencional deficits. Brain Lang. 2001;77(2):216-40

3. Kelly SD. Broadening the units of analysis in communication: speech and nonverbal behaviours in pragmatic comprehension. J. Child Lang. 2001;28(2):32549.

4. Chan JB, Iacono T. Gesture and word production in children with Down syndrome. AAC. 2001;17(2):73-87.

5. Chapman RS, Hesketh LJ, Kistler DJ. Predicting longitudinal change in language production and comprehension in individuals with Down syndrome: hierarchial linear modeling. J Speech Lang Hear Res. 2002; 45(5):902-15

6. Miles S, Chapman RS. Narrative content as described by individuals with Downs syndrome and typically developing children. J Speech Lang Hear Res. 2002;45(1):175-89.

7. Laws G, Bishop DVM. Pragmatic language impairment and social deficits in Williams syndrome: a comparison with Down's syndrome and specific language impairment. Int J Lang Commun Disord. 2004;39(1):45-64.

8. Hick RF, Botting N, Conti-Ramsden, G. Short-term memory and vocabulary development in children with Down syndrome and children with specific language impairment. Dev Med Child Neurol. 2005;47(8):532-8.

9. Iverson JM, Goldin-Meadow S. Gesture paves the way for language development. Psychol Sci. 2005;16(5):36771 .

10. Ozçaliskan S, Goldin-Meadow S. Do parents lead their children by the hand? J Child Lang. 2005;32(3):481-505.

11. Flabiano FC, Porto E, Limongi SCO. Cognition development and communicative profile in toddlers with Down syndrome. Annual ASHA Convention, 2007, Boston - MA. ASHA Annual Convention Proceedings, 2007.

12. Silverman W. Down syndrome: cognitive phenotype. Ment Retard Dev Disabil Res Rev. 2007,13(3):228-36.

13. Stefanini S, Caselli MC, Volterra V. Spoken and gestural production in a naming task by young children with Down syndrome. Brain Lang. 2007;101(3):208-21.

14. Chapman RS, Hesketh LJ. Behavioral phenotype of individual with Down syndrome. Ment Retard Dev Disabil Res Rev. 2000;6(2):84-95.

15. Rondal JA. Síndrome de Down. In: Bishop D, Mogford K. Desenvolvimento da linguagem em circunstâncias excepcionais. Tradução de: Lomba M P, Lankszner L. São Paulo: Revinter; 2002. p. 225-42.

16. Abbeduto L, Warren SF, Conners FA. Language development in Down syndrome: from the prelinguistic period to the acquisition of literacy. Ment Retard Dev Disabil Res Rev. 2007;13(3):247-61.
17. Johnston F, Stansfield J. Expressive pragmatic skills in pre-school children with and without Down's syndrome: parental perceptions. J Intellect Disabil Res. 1997; 41(1):19-29.

18. Bradley RH, Corwyn RF. Socioeconomic status and child development. Annu Rev Psychol. 2002;53:371-99.

19. Sapienza G, Pedromônico MRM. Risco, proteção e resiliência no desenvolvimento da criança e do adolescente. Psico Estud (Maringá). 2005;10(2):209-16.

20. Andrade AS, Santos DN, Bastos AC, Pedromônico MRM, Almeida-Filho N, Barreto ML. Ambiente familiar e desenvolvimento cognitivo infantil: uma abordagem epidemiológica. Rev Saúde Pública. 2005;39(4):606-11.

21. Andrade RV, Limongi SCO. O processo terapêutico fonoaudiológico de crianças pequenas portadoras de síndrome de Down e a orientação à família. Rev Soc Bras Fonoaudiol. 2001;2(2):29-33.

22. Nascimento IT, Teixeira LC, Zarzar PMPA. Bioética: esclarecimento e fonoaudiologia. Rev CEFAC. 2009; 11(1):158-65.

23. Fernandes FDM. Pragmática. In: Andrade CRF, BefiLopes DM, Fernandes FDM, Wertzner H. ABFW - Teste de linguagem infantil nas áreas de fonologia, vocabulário, fluência e pragmática. Barueri: Pró-Fono; 2004. p. 83-97.

24. Westphal AC, Alonso NB, Silva TI, Azevedo AM, Caboclo LOSF, Garzom E, Sakamoto AC, Yacubian EMT. Comparação da qualidade de vida e sobrecarga dos cuidadores de pacientes com epilepsia por esclerose mesial temporal e epilepicia mioclônica juvenil. J Epilepsy Clin Neurophysiol. 2005;11(2):71-6.

25. Associação Brasileira de Estudos Populacionais [online]. Critério de Classificação Econômica Brasil. Brasil: ABEP; 2003. Disponível em www.abep.org/codigosguias/ ABEP_CCEB.pdf

26. Limongi SCO, Carvallo RMM, Souza ER. Auditory processing and language in Down syndrome. J Med Speech Lang Pathol. 2000;8(1):27-34.

27. Cardoso C. Funções comunicativas em diferentes situações com crianças do espectro autístico. Rev Soc Bras Fonoaudiol. 2006;11(1):22-7.

28. Wetherby AM, Prutting CA. Profiles of communicative and cognitive-social abilities in autistic children. J Speech Hear Res. 1984;27:364-77.

29. Fernandes FDM. Atuação fonoaudiológica com crianças com transtornos do espectro autístico [livre-docência]. São Paulo: Faculdade de Medicina, Universidade de São Paulo; 2002.

30. Porto E, Santos IG, Limongi SCO, Fernandes FDM. Amostra de filmagem e análise da pragmática em crianças com síndrome de Down. Pró-Fono. 2007;19(2):159-66. 